\title{
SANDRINE HÉRICHÉ-PRADEAU, Le trésor au Moyen Âge: creuser la terre, explorer la langue
}

\section{Maria Colombo Timelli}

\section{(2) OpenEdition \\ 12 Journals}

Édition électronique

URL : https://journals.openedition.org/studifrancesi/46709

DOI : 10.4000/studifrancesi.46709

ISSN : 2421-5856

Éditeur

Rosenberg \& Sellier

\section{Édition imprimée}

Date de publication : 1 décembre 2021

Pagination : 578

ISSN : 0039-2944

\section{Référence électronique}

Maria Colombo Timelli, « SANDRINE HÉRICHÉ-PRADEAU, Le trésor au Moyen Âge: creuser la terre, explorer la langue », Studi Francesi [En ligne], 195 (LXV | III) | 2021, mis en ligne le 01 décembre 2021, consulté le 07 décembre 2022. URL : http://journals.openedition.org/studifrancesi/46709; DOI : https://doi.org/ 10.4000/studifrancesi.46709

Ce document a été généré automatiquement le 7 décembre 2022.

\section{cc)}

Creative Commons - Attribution - Pas d'Utilisation Commerciale - Pas de Modification 4.0 International - CC BY-NC-ND 4.0

https://creativecommons.org/licenses/by-nc-nd/4.0/ 


\title{
SANDRINE HÉRICHÉ-PRADEAU, Le trésor au Moyen Âge: creuser la terre, explorer la langue
}

\author{
Maria Colombo Timelli
}

\section{RÉFÉRENCE}

SANDRINE HÉRICHÉ-PRADEAU, Le trésor au Moyen Âge: creuser la terre, explorer la langue, dans Un Trésor de textes. Images, présences et métaphores du trésor dans la langue et la littérature françaises, Études réunies par A. BETTONI et M. PIVA, Firenze, Olschki, 2020, pp. 15-28.

1 Foncièrement ambigu, le mot «trésor» peut référer en français médiéval tant aux bien terrestres qu'aux biens spirituels, tant à un contenant qu'à un contenu. À partir du constat de cette richesse sémantique, S.H.-P. organise sa réflexion en deux volets. Elle dresse d'abord un riche inventaire des œuvres qui exhibent le vocable dans leur titre, à partir de la plus célèbre d'entre elles, le Tresor de Brunet Latin, jusqu'à des textes beaucoup moins connus, composés au xve siècle; son corpus, qui comprend entre autres le Tresor des Hystoires ou Tresor de Sapience (titres derrière lesquels est transmise la Chronique dite de Baudouin d'Avesnes), le Tresor de Sapience de Jean Gerson, le Tresor de l'ame de Robert le Chartreux, le Tresor de Vanerie, et encore le Tresor de noblesse d'Octovien de Saint-Gelais, a le mérite d'inclure les œuvres qui voient leur titre se modifier lors du passage à l'imprimé: ainsi, la Doctrina Pueril de Raymon Llull (1275) devient le Tresor des humains dans deux incunables de 1482, le Livre des trois vertus de Christine de Pizan (1405) prend le titre de Tresor de la cité des dames chez Antoine Vérard (1497), le Livre de bonnes meurs de Jacques Legrand (1404-1410) sera publié sous le titre de Tresor de Sapience un peu plus tard, en 1530.

2 La deuxième partie reconstitue les champs sémantiques qui s'organisent, notamment dans les prologues, autour du noyau «trésor»: les notions qui priment sont celles de 
l'accumulation (par exemple par la métaphore du trésor-livre), puis celle de la mémoire (métaphore de l'«aumaire» ou du coffre), et surtout celle de la circulation d'un savoir total, qu'il s'agit d'extraire - éventuellement par le procédé de la traduction - afin de le conserver et de le transmettre. 